\title{
Similarities between Korean and Japanese
}

\author{
Seyoung Oh and Taeseon Yoon
}

\begin{abstract}
As Korea and Japan has long time of history for exchanging each other's cultural aspects, they have many kinds of similar things. Among them, language is one of the most things which have many kinds of similar aspects. By portraying similarities between two languages, we could find out each language's developmental stages and through this understanding each language's consciousness structure becomes easier. However, as relationship between Korea and Japan becomes deteriorated due to many kinds of political and historical issues, contrastive researches between two languages lost interests from many researchers. This paper, in recognition of necessities to undergo the research about similarities between two languages, intends to find the intimate traits between two languages related to grammatical traits and conversation culture. Through this paper, supposition that Korean and Japanese are similar because of their shared historical traits would become clearer.
\end{abstract}

Index Terms - Similarity, Japanese and Korean, grammatical trait, conversation culture.

\section{INTRODUCTION}

Since both Korean and Japanese can be categorized as a language which is affected by Chinese language and character there are many kinds of similarities which can be traced in a cultural area of Chinese character. First, one is that both languages have a complex system of honorific system. In western language even though there could be expressions which show respect to others there is no fixed honorific system which must be used in specific cases in specific form. However, in case of Korean and Japanese there is a fixed honorific system. This system can be divided into 2 different systems which are humble system and admiration system. The former system is realized by using an expression that lowers narrator himself, but the latter is realized by using an expression which respects other people's action. For instance, '聞<' 'and '묻다'(muk-da) which means ask in Japanese and Korean respectively can be realized into 2 honorific systems which I mentioned above. If we use the former system, ‘聞 く'becomes ‘伺う’or ‘お聞きする'and ‘묻다' becomes '여쭙다'(yeo-zzub-da) which are lowering narrator's action in order to show respect to a companion of conversation. On the other hand, if we use the latter system which is used in order to directly give respects to interlocutor's action, ‘聞 く'becomes ‘お伺いになる’or“お聞きになる’and ‘묻다'becomes '물으시다'(mul-ui-si-da). There are also

Manuscript received December 26, 2015; revised March 11, 2016 Seyoung Oh is with the Hankuk Academy of Foreign Studies, Yonginsi, South Korea (e-mail: seval0301@ naver.com).

Taeseon Yoon was with Korea University, Seoul, South Korea. He is now with Hankuk Academy of Foreign Studies, Yonginsi, South Korea (e-mail: tsyoon@hafs.hs.kr). similarities which are related to the usage of postposition and arrangements of word. Unlike western languages, Korean and Japanese have a form of $[\mathrm{S}$ (subject) $+\mathrm{O}($ object $)+\mathrm{V}($ verb $)]$. This is a very special trait limited to Korean and Japanese, because Chinese language which shares same back ground has a $[\mathrm{S}$ (subject) $+\mathrm{V}($ verb $)+\mathrm{O}($ object $)]$ unlike Japanese or Korean. In case of postposition, as there are many kinds of postpositions and as same postpositions can be used in different meaning in different environment, if we try to say that postposition is a similar point then it should be verified in many kinds of situation. For example, similarities between' 2 'and Korean '-에' (eo) can be a great example of similarities in postposition. Therefore aggregating all these kinds of similarities, this research would like to study about speech-act similarities between Korean and Japanese.

\section{PROCEDURE FOR PAPER SUBMISSION}

The related researches are scattered in various fields but it could be categorized in 3 big areas. They are contrastive research related to honorific system between Korean and Japanese, sentence structures between two languages and finally, how meaning of postpositions could be realized in different environment. As my research is trying to verify the similarities between these two languages, this paper will cover all of these categories and each field's research result can be used as supporting basis. This concentrates on the similarities between Korean and Japanese sentence's application of predicates. As both Japanese and Korean languages make much of its meaning through usage of helping verbs and modification of word final it is focusing on the order of helping verbs and ending [1]. This reported a research on contrastive researches between Korean postposition '-의'(ui) and Japanese postposition 'の'. It concentrated on skip and realization of ' $の$ ' and applied results into Korean sentences. And using this method this research tries to find out suitable way to teach Japanese to Korean as foreign language [2]. This reported a research on differences between Korean postpositions '-에'(eo)and '-에서'(eo-seo). After finding out differences it is trying to apply its semantic context into Japanese postpositions 'に’and ‘で'. By applying this semantic context into Japanese, this research ultimately aims to teach differences of Korean postpositions to Japanese who are learning Korean [3]. This reported a contrastive research on honorific system between Korean and Japanese. It targets a honorific system after World War II. As this research is a contrastive research, it both targets on similarities and differences between two languages. Also it prospects future of the honorific system [4].

Through this related research, we could find out that attempts to find out similarities between Korean and Japanese 
have developed in various fields. This paper will make a comprehensive survey of research related to this field.

\section{EXPERIMENT}

\section{A. Similarities}

TABLE I: SIMILARITIES OF WORD ORDERS BETWEEN KOREAN AND JAPANESE

\begin{tabular}{|c|c|c|c|}
\hline & Korean & Japanese & English \\
\hline Active voice $<6>$ & $\begin{array}{l}\text { 나는 밥을 } \\
\text { 먹는다. }\end{array}$ & $\begin{array}{l}\text { 私は ご飯 } \\
\text { を 食べ } \\
\text { る。 }\end{array}$ & $\begin{array}{l}\text { I have a } \\
\text { meal. }\end{array}$ \\
\hline Passive voice <7> & $\begin{array}{l}\frac{\text { 물고기가 }}{\text { 곰에게 }} \\
\text { 먹혔다. }\end{array}$ & $\begin{array}{l}\text { 魚がクマ } \\
\text { に食べら } \\
\text { れた。 }\end{array}$ & $\begin{array}{l}\text { A fish was } \\
\text { eaten by a } \\
\text { bear. }\end{array}$ \\
\hline $\begin{array}{l}\text { Past supposition } \\
\text { phrase }<8>\end{array}$ & $\begin{array}{l}\text { 그는 잠을 } \\
\text { 잤겠더라. }\end{array}$ & $\begin{array}{l}\text { 彼は 睡眠 } \\
\text { を } \\
\text { 取っただ } \\
\text { ろう。 }\end{array}$ & $\begin{array}{l}\mathrm{He} \quad \text { would } \\
\text { have taken } \\
\text { a sleep. }\end{array}$ \\
\hline \multirow[t]{2}{*}{$\begin{array}{l}\text { Negative } \\
\text { supposition } \\
\text { phrase }<9>\end{array}$} & $\begin{array}{l}\text { 이 과자는 } \\
\text { 그다지 } \\
\text { 맛있을 것 } \\
\text { 같지 않다. }\end{array}$ & $\begin{array}{l}\text { このお菓 } \\
\text { 子はあま } \\
\text { りおいし } \\
\text { そうにも } \\
\text { ない。 }\end{array}$ & $\begin{array}{l}\text { This snack } \\
\text { doesn't } \\
\text { look good } \\
\text { at all. }\end{array}$ \\
\hline & $\begin{array}{l}\text { 이 과자는 } \\
\text { 별로 } \\
\text { 맛없을 것 } \\
\text { 같다. }\end{array}$ & $\begin{array}{l}\text { このお菓 } \\
\text { 子はあま } \\
\text { りおいし } \\
\text { くなさそ } \\
\text { うだ。 }\end{array}$ & \\
\hline
\end{tabular}

Through Table I the fact that word orders between Korean and Japanese are similar could be easily found out. Let's see example <6>. (Starting from now I will only use number in order to quote an example easily.) It is a basic form which doesn't have any kind of other grammatical devices. As we can find out, unlike English word order which takes a form of $\mathrm{S}$ (subject)+V(verb)+O(object), Korean and Japanese sentence follows a word order of $\mathrm{S}$ (subject)+O(object) $+\mathrm{V}$ (verb) which is different from that of English. This trait is also found in example $<7>$. In case of Korean and Japanese adverb comes right after the subject. So the structure of sentence becomes $[\mathrm{S}($ subject $)+\mathrm{A}($ adverb $)+\mathrm{V}($ verb $)]$ which is totally nonsense in English. In example $<8>$ a position of helping verb could be find out. In Korean and Japanese instead of using helping verb, an ending is transformed into different form. Also, although helping verb comes before main verb in case of English, Korean and Japanese takes a structure of transformation after main verb. In example <9>, we could find out that one English sentence can be translated into two different Korean and Japanese sentences which have different structures. Korean and Japanese can express a negative supposition into 2 ways. They can use a word which means negative supposition or they deny the supposition by using a helping verb which is a negative phrase.

Table II gives an example of honorific system which is essential in both Korean and Japanese. There are many categories of honorific system that Korean and Japanese share similarities. In example $\langle 10\rangle$ we could find an honorific system. In case of Korean '-습니다' (sub-ni-da), and
Japanese ‘一ます’ is used in order to honor the listener (in this case grandmother). However, this kind of expression is not found in English. In case of example <11 > the thing which is important is that honorific system can be changed in different situations. Naturally, honorific system must be used to '사장님'(sa-jang-nim) and '社長'. However, as there is a guest who is not in speaker's group, guest should be honored much more than '사장님'or '社長' who shares a same group with a speaker. For this reason, honorific system is not used to both '사장님'and '社長'. In example $<12>$ an expression which lowers speaker's action is used in order to talk in a polite way. In this case speaker's action is lowered through a usage of a special verb, and through that, naturally object becomes higher. In example $\langle 13\rangle$ we could find out that special verb is used which only has a meaning of honorification. In case of '계십니다' (keo-sib-ni-da), '있으십니다' (ik-sub-ni-da) which just simply made through applying grammatical formula could be used. However, a level becomes much higher by using of special verb rather than just applying grammatical formula. It is also found in

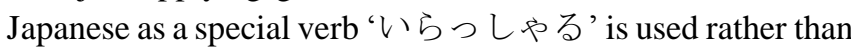
using a ‘います’which just simply applied a grammatical formulation. Finally, in example $\langle 14>$ we could find out the fact that there is a special word which is used in honorification. In case of Korean and Japanese a word father has a different form of ‘아빠/아버지'(a-pa/a-beo-ji)or '父/お父さん’. This is one of the most important features of Korean and Japanese because this fact shows that these 2 languages could diversify honorification not only transformation of verb but also usage of special noun and other language elements.

TABLE II: SIMILARITIES OF HONORIFIC SYSTEM BETWEEN KOREAN AND JAPANESE

\begin{tabular}{|c|c|c|c|}
\hline & Korean & Japanese & English \\
\hline $\begin{array}{l}\text { Honorific } \\
\text { System. }<10>\end{array}$ & $\begin{array}{l}\text { 할머니 } \\
\text { 제가 밥을 } \\
\text { 먹었습니 } \\
\text { 다. }\end{array}$ & 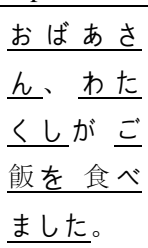 & $\begin{array}{l}\text { Grandmoth } \\
\text { er, I had a } \\
\text { meal. }\end{array}$ \\
\hline $\begin{array}{l}\text { Division of } \\
\text { group }<11>\end{array}$ & $\begin{array}{l}\text { 손님, } \\
\text { 사장님이 } \\
\frac{\text { 아직 안 }}{\text { 왔습니다. }}\end{array}$ & $\begin{array}{l}\text { お客様、 } \\
\frac{\text { 踣長が }}{\text { だ来てな }} \\
\text { いです。 }\end{array}$ & $\begin{array}{l}\text { Sir, CEO } \\
\text { hasn't come } \\
\text { yet. }\end{array}$ \\
\hline $\begin{array}{l}\text { Honorific } \\
\text { system }<12>\end{array}$ & $\begin{array}{l}\text { 내가 } \\
\text { 선생님께 } \\
\text { 질문을 } \\
\text { 여쭈었다. }\end{array}$ & $\begin{array}{l}\text { 私が先生 } \\
\text { に質問を } \\
\text { 伺った。 }\end{array}$ & $\begin{array}{l}\text { I asked a } \\
\text { question to } \\
\text { teacher. }\end{array}$ \\
\hline $\begin{array}{l}\text { Usage of special } \\
\text { verb }<13>\end{array}$ & $\begin{array}{l}\text { 선생님, } \\
\text { 계십니까? }\end{array}$ & $\begin{array}{l}\text { 先生、少 } \\
\text { らっし や } \\
\text { 小 } \\
\text { か }\end{array}$ & $\begin{array}{l}\text { Is there a } \\
\text { teacher? }\end{array}$ \\
\hline $\begin{array}{l}\text { Specific } \\
\text { expression }<14>\end{array}$ & $\begin{array}{l}\text { 아빠/ } \\
\text { 아버지 }\end{array}$ & $\begin{array}{l}\text { お父さんl } \\
\text { 父(ちち) }\end{array}$ & Father \\
\hline
\end{tabular}

Usage of postposition which are mentioned in Table III is one of the most important features that are shared between Korean and Japanese. In example $<15>$ '의' and ' $\sigma$ ' is both 
used in order to express one's possession. Unlike English, both Korean and Japanese don't have to use verb in order to express one's possession. In example $<16>$ it points out a unique feature that is shared between Korean and Japanese. In Korean and Japanese, postpositions can be unified. In English a very limited group of preposition can be unified in a very limited situation. However, in case of Korean and Japanese post positions can be unified relative easily. Not only postpositions which are mentioned above there many kinds of unified forms of postpositions. In example <17> this postposition is important because this postposition can be used only in a place where action is occurred. It is different from English because in case of 'at' it covers not only place but time. Unlike 'at', '-에서' and '-で' could be used only in a place [5]. In example $\langle 18>$, it shows a case that postpositions can be used as a noun. 3 examples which I mentioned before only show a postposition's roles that could be translated into a role of preposition. However, in example <4> we could find out that postposition can be also used as a noun. What is important is that, in this case only '것' and ' $\sigma$ ' can be used. Finally, in example <19> we could commonly say that this is the main role of '-의' and ' $\sigma$ ' [6]. As we can find out in this example, postposition acts as a conjunction of noun phrases or it can act as a qualifier. This kind of usage is frequently found in both Korean and Japanese. '-의' and ', ' can both act as an English conjunction or linker.

TABLE III: SIMILARITIES OF USAGE OF POSTPOSITIONS BETWEEN KOREAN AND JAPANESE

\begin{tabular}{|c|c|c|c|}
\hline & Korean & Japanese & English \\
\hline Possession $\langle 15\rangle$ & $\begin{array}{l}\text { 그것은 } \\
\text { 나의 } \\
\text { 것이다. }\end{array}$ & $\begin{array}{l}\text { それは } \\
\text { 私のです }\end{array}$ & $\begin{array}{l}\text { That's } \\
\text { mine. }\end{array}$ \\
\hline $\begin{array}{l}\text { Unification of } \\
\text { postpositions }<16>\end{array}$ & $\begin{array}{l}\text { 학생으로 } \\
\text { 서의 본분 }\end{array}$ & $\frac{\text { 学生亡し }}{\text { ての本分 }}$ & $\begin{array}{l}\text { A student's } \\
\text { duty. }\end{array}$ \\
\hline $\begin{array}{l}\text { Place of } \\
\text { action }\langle 17>\end{array}$ & $\begin{array}{l}\text { 나는 } \\
\text { 은행에서 } \\
\text { 일한다. }\end{array}$ & $\begin{array}{l}\text { 私は銀行 } \\
\text { で働いて } \\
\text { います。 }\end{array}$ & $\begin{array}{l}\text { I work at } \\
\text { bank. }\end{array}$ \\
\hline $\begin{array}{l}\text { Case or } \\
\text { Situation }<18>\end{array}$ & $\begin{array}{l}\text { 그가 } \\
\text { 은행에 } \\
\text { 들어가는 } \\
\text { 것을 } \\
\text { 보았다. }\end{array}$ & $\begin{array}{l}\text { 彼が 銀行 } \\
\text { に入る吕 } \\
\text { を見た。 }\end{array}$ & $\begin{array}{lr}\text { I saw } & \text { him } \\
\text { going } & \text { to } \\
\text { bank. } & \end{array}$ \\
\hline $\begin{array}{l}\text { Listing noun or } \\
\text { modification }<19>\end{array}$ & $\begin{array}{l}\text { 그것은 } \\
\text { 한국의 } \\
\text { 국화인 } \\
\text { 무궁화이 } \\
\text { 다. }\end{array}$ & $\begin{array}{l}\text { それは韓 } \\
\text { 国の国花 } \\
\text { の槿だ。 }\end{array}$ & $\begin{array}{l}\text { That is a } \\
\text { rose of } \\
\text { Sharon } \\
\text { which is } \\
\text { Korean } \\
\text { national } \\
\text { flower. }\end{array}$ \\
\hline
\end{tabular}

We can find out many kinds of similarities between Korean and Japanese in Table IV. First collocation expression is especially detected in Korean because it is related with the usage of verb, subject and postpositions. First category is syntagmatic collocation which is related to a structure of sentence. As we can find out in these examples, Korean and Japanese languages show a same collocation structure in case of syntagmatic collocation. For instance, in example <20> underlined word could be translated into reddest. However, both in Korean and Japanese this word could only be united with a word 'lie'. In case of example $<21>,<22>,<23>,<24>$, arrangements of postpositions and verb are same. Interesting point related to this category is that although this is habit of each language it is not related to grammatical facts because it doesn't have fixed rules. Secondly, in case of paradigmatic collocation it is closely related to meaning rather than expression. In case of $\langle 27\rangle$ these two sentences have a same meaning which means that he lends a book to her. However, sentences which have same meaning can be changed in formation through modification of postpositions and verbs, and these kinds of formation show a same form between Korean and Japanese. Also, Korean and Japanese antonym system can be categorized into 4 groups. In case of example $<26>$, it shows 4 categories which are 'size', 'opposite action', 'opposite situation', and finally 'fact of existence or nonexistence'. In example $<25>$, we can find out that both languages have a same synonym structure and even same word expressions.

TABLE IV: SIMILARITIES OF COLLOCATION EXPRESSION BETWEEN KOREAN AND JAPANESE

\begin{tabular}{|c|c|c|c|}
\hline $\begin{array}{c}\text { Classification by } \\
\text { relation }\end{array}$ & $\begin{array}{c}\text { Classification } \\
\text { by meaning }\end{array}$ & $\begin{array}{l}\text { Examples } \\
\text { (Korean) }\end{array}$ & $\begin{array}{c}\text { Examples } \\
\text { (Japanese) }\end{array}$ \\
\hline \multirow{34}{*}{$\begin{array}{l}\text { Syntagmatic } \\
\text { Collocation }\end{array}$} & \multirow[t]{16}{*}{ Emphasis $<20>$} & 새빨간 & 真つ赤な \\
\hline & & 거짓말 & うと \\
\hline & & 삼십 전, & 泣くほど \\
\hline & & 오십 전 & 嬉しい時 \\
\hline & & 쌓이는 & もよろし \\
\hline & & 돈에 & いでしょ \\
\hline & & 눈물이 날 & $\begin{array}{l}\text { 与? } \\
\text { (用讱职子) }\end{array}$ \\
\hline & & 정도로 & \\
\hline & & 기쁘다.(현 & \\
\hline & & 진건 & \\
\hline & & 운수좋은 & \\
\hline & & 날) & \\
\hline & & 배꼽이 & 腹の皮を \\
\hline & & 빠질 & よるほど \\
\hline & & 정도로 & \\
\hline & & 웃기다. & \\
\hline & \multirow{6}{*}{$\begin{array}{l}\text { Functioning } \\
<21>\end{array}$} & 모자를 & 帽子豆と \\
\hline & & 벗다. & \\
\hline & & 안경을 & 眼鏡をと \\
\hline & & 벗다. & る。 \\
\hline & & 모자를 & 帽子至か \\
\hline & & 쓰다. & ぶる。 \\
\hline & \multirow{4}{*}{$\begin{array}{l}\text { Creation } \\
<22>\end{array}$} & 집을 짓다. & 家を建て \\
\hline & & & \\
\hline & & 소설을 & 小説を書 \\
\hline & & 쓰다. & \\
\hline & \multirow{4}{*}{$\begin{array}{l}\text { Disappear } \\
<23>\end{array}$} & 열이 & 熱が取れ \\
\hline & & 가시다 & $\underline{\text { z }}$ \\
\hline & & 피로가 & 疲れが取 \\
\hline & & 가시다. & れる \\
\hline & \multirow{4}{*}{$\begin{array}{l}\text { Deterioration } \\
<24>\end{array}$} & 야채가 & 野菜孞腐 \\
\hline & & 썩다. & 万 \\
\hline & & 목소리가 & 声がつぶ \\
\hline & & 쉬다. & \\
\hline
\end{tabular}




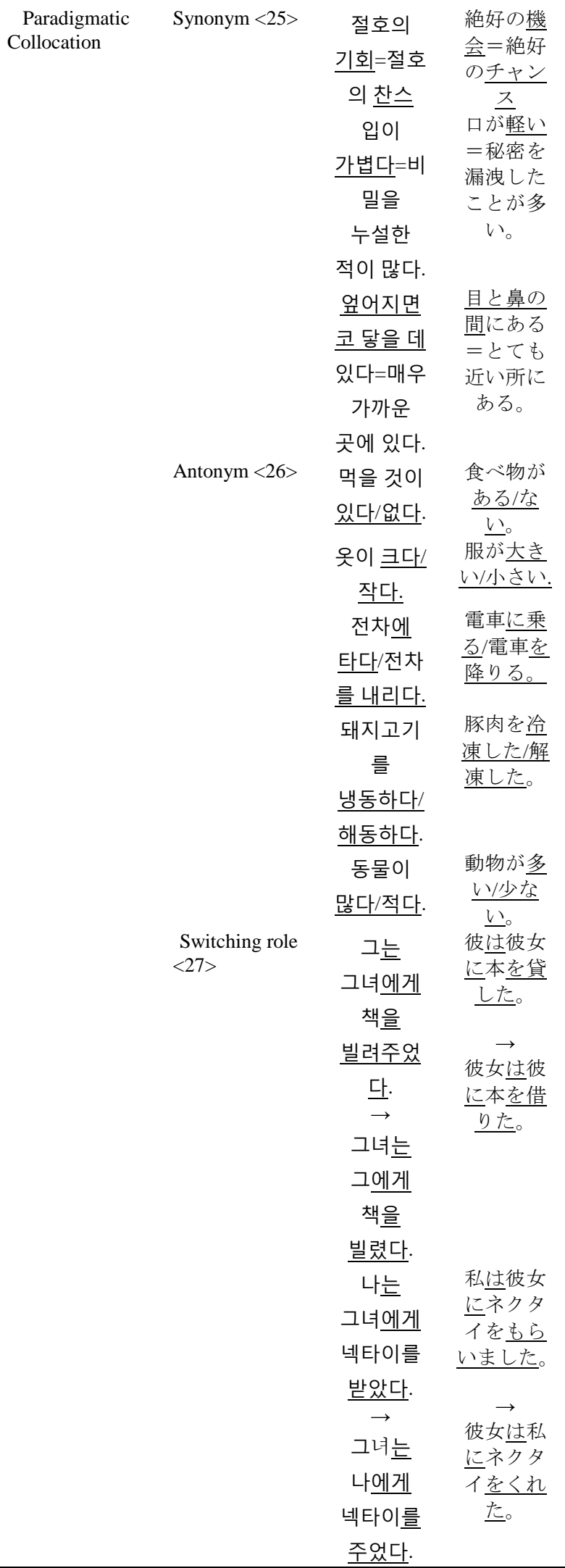

\section{B. Reason}

Then how can it be possible that these two languages have such similarities? In this paper we could point out 3 reasons which are related to similarities. First reason is that 2 languages have Ural-Altaic language systems. Even though there are many controversies related to stratum of Japanese, majority of researchers are arguing that Japanese's stratum is either Ural-Altaic or mixture of Ural-Altaic and South-Indian
[7]. For example, in case of word orders they are only detected (which have a form of subject+predicate+modifier+modificand) in case of Ural-Altaic language. Also, realizing various kinds of meaning through the application of ending of a verb shows an agglutinative language's trait. And this kind of characteristic is only detectable in case of Ural-Altaic languages. Secondly, in case of honorific system this would be related to similar socio-economic conditions between Korea and Japan. Korea and Japan both had a fixed class system which has never been changed for more than thousands of years. So, honorific system would be a language system which would be different between classes, and this system would be changed into a contemporary honorific system as class system is collapsed. In fact, honorific system of Japan was change in 1868 when the Meiji Restoration was occurred due to a collapse of class system [8].

Finally, usage of certain postpositions would be related to the influence of Japan. Among them ' $\sigma$ ' can be the best example. In Korean '-의' which has same meaning as Japanese ' $の$ ' had rarely been used until the middle of $18^{\text {th }}$ century. It has been started to use widely after Japanese started to widen their power in Korea, and it finally took a root for a period of Japanese colonial era against Korea.

\section{CONCLUSION}

The limitation of this research is that subtle differences between Korean and Japanese are not considered sufficiently. Even though most of the things which are mentioned in this paper are similarities there could be slight differences. But as there are many other arguments it is hard to mention them in this paper. Also there is another limitation which is related to precise explanation. As definition of phraseology is little bit vague, it might cause confusion. However, even though there might be slight differences, as overall features are similar and there are many related researches about similarities between Korean and Japanese it would be alright to say that both languages share similarities. What's more, even though it is mostly considered that Korean and Japanese share similarities, yet it is not considered carefully. As mutual relation between languages becomes much more important, I hope that this research will serve as catalyst in order to increase a study related to contrastive research between Korean and Japanese.

Also this research has a value that it tries to find out reasons for similarities between two languages. This research not only dealt with philological aspect but dealt with both socio-economical and historical aspects. This research can show that both Korea and Japan share not only linguistic likeness but also socio-economical and historical similarities.

\section{REFERENCES}

[1] M. Kim, The Contrastive Study of Korean and Japanese Predicate Structure, 2002.

[2] G. Bang, "A contrastive study of politeness expressions in early twentieth century Korean and Japanese language," The Japanese Modern Association of Korea the Japanese Modern Association of Korea, pp. 37-52, 2008

[3] M. Lee, "Reviewing the methodology of contrastive study of Korean and Japanese - Focusing Onshite-shimau," Journal of Japanese Language and Culture, pp. 157-175, 2007. 
[4] M. Park, A Comparative Research of Honorification in Korean and Japanese, 1998.

[5] S. Jung, The Study of Acquisition of Semantic functions of ' $e$ ' and 'eseo' by Japanese learners of Korean, 2015.

[6] S. Cho, A Comparative Study on the Postposition 'ui' of Japanese and 'no' Korean Languages, 1996.

[7] N. Lee, The Problem of the Genetic Relationship between the Japanese Language and the Korean Language and the Methods of Comparative Study.

[8] K. Mabuchi, Japanese Root and Korean, the Japanese Language and Literature Association of Korea.

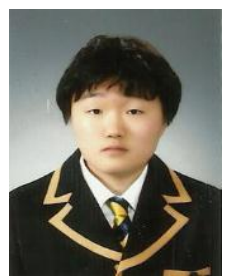

Seyoung Oh was born in Seoul, Korea, in 1998. He was a student of Joongdong Academy from 2011 to 2013. He has been a student of HAFS (Hankuk Academy of Foreign Studies) since 2014. He is now major in humanities and Japanese.

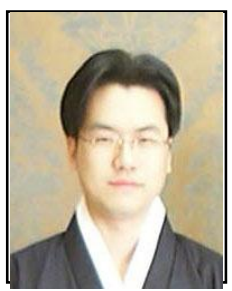

Taeseon Yoon was born in Seoul, Korea, in 1972. He got a Ph.D. degree in computer education from the Korea University, Seoul, Korea, in 2003.

From 1998 to 2003, he was with EJB analyst and SCJP. From 2003 to 2004, he joined the Department of Computer Education, University of Korea, as a lecturer and Ansan University, as an adjunct professor. Since December 2004, he has been with the Hankuk Academy of Foreign Studies, where he was a computer science and statistics teacher. 